\title{
Effect of Different Dietary Crude Protein Levels and Citric Acid on Broiler Chickens' Performance, Carcass Characteristics, Intestinal Morphology, and Blood Components
}

\author{
Mamdouh Omar Abd-Elsamee ${ }^{1}$, Hady Fathy Abbas Motawe ${ }^{2}$, Mostafa Maher Selim ${ }^{2 *}$, and Hany Mohamed \\ Ramadan Elsherif ${ }^{1}$ \\ ${ }^{I}$ Department of Animal Production, Faculty of Agriculture, Cairo University, Giza, Egypt \\ ${ }^{2}$ Regional Centre for food and feed (RCFF), Agricultural Research Center, Giza, Egypt \\ *Corresponding author's Email: mostafa.m.selim@gmail.com; (iDORCID: 0000-0002-6072-812X
}

\begin{abstract}
The present study was conducted to investigate the effect of dietary protein levels and citric acid on the growth performance, carcass yield, abdominal fat, chemical composition of meat, intestinal morphology, and blood parameters of broiler chickens. A total of $160 \mathrm{Cobb} 500$ unsexed one-day-old broilers were assigned to 4 dietary treatments, 4 replicates of 10 chickens each. A factorial design arrangement $2 \times 2$ was used, including two protein levels, $100 \%$ (optimal level) and $90 \%$ (low level) of recommended dietary crude protein for cobb 500 broiler chickens, each protein level supplemented with or without 20-gram citric acid $/ \mathrm{kg}$. The results showed that chickens fed the diet containing 100\% required Crude Protein (CP) supplemented with citric acid which could significantly improve body weight gain, feed conversion ratio, carcass yield, abdominal fat, fat content in meat, intestinal morphology, cecal microbial content, and blood parameters (Albumin, haemoglobin Ac1, fructosamine, and cholesterol). Chickens fed the low CP diet supplemented with citric acid could compensate for the growth performance equivalent to those fed the optimal CP diet. Both required protein level and citric acid were significantly improved blood albumin and reduced haemoglobin Ac1 and fructosamine, which could serve as indicators of the blood protein glycation. In conclusion, citric acid addition could alleviate the negative effect of feeding broiler chickens on low CP diets through its beneficial impact on intestinal morphology, cecal bacterial counts, blood cholesterol reduction, and glycated proteins.
\end{abstract}

Keywords: Broiler, Citric Acid, Glycation, Performance, Protein level

\section{INTRODUCTION}

It is of utmost significance for the livestock industry to benefit from inexpensive, highly efficient, and safe diets. Inclusion of low crude protein content in poultry diets can be considered as one of the effective strategies to reduce ammonia emission from poultry wastes, environmental impact, and diet costs (Belloir et al., 2017 and Barekatain et al., 2019). However, such diets can result in negative consequences, including poor growth performance and carcass yield of broilers (Bregendahl et al., 2002; Liu et al., 2017; Allameh and Toghyani, 2019). The negative effect of a low protein diet on chickens' growth performance might be attributed to the effects of protein deficiency on intestinal morphological changes (Yu et al., 2019). Therefore, nutritionists have developed strategies to lessen the negative effects of the low CP diets on broiler chickens' growth performance (Kermani et al., 2017; Goodarzi Boroojeni et al., 2018 and Sharifuzzaman et al., 2020).

Many endogenous factors limited protein utilization in the chickens' diet, such as gastrointestinal tract physiology, oxidative stress, and glycation. Glycation is one of the non-enzymatic reactions observed in avian species, which might reduce amino acids' nutritional value, therefore low glycation of protein and amino acids could enhance poultry performance (Makino et al., 2015). On the other hand, the low dietary protein could increase the glycated amino acids in chicken plasma (Honma et al., 2017). Therefore, diet adjustments or food additives could be considered as early prevention against glycation (Guilbaud et al., 2016).

As reported, human consumption of several compounds, such as organic acids, minerals, and probiotics induce antiglycation activity. These compounds, especially organic acids, had been used as alternatives for antibiotics (Polycarpo et al., 2017) and growth promoters in poultry diets (Sabour et al., 2019 and Adhikari et al., 2020). Several studies lend support to the effects of organic acids, especially citric acid, on the enhancement of growth performance (Islam et al., 2011 and Tanzin et al., 2015), carcass yield (Lakshmi et al., 2016), and intestinal histology (Khosravinia et al., 2015). Therefore, the current study aimed to evaluate the impact of adding citric acid to broiler diets with protein levels on growth performance, carcass characteristics, intestinal morphometry, microbiota, and blood biochemical parameters. 
This six-week study was conducted between March and April 2019 at the Poultry Research Unit, Regional Center for Food and Feed (RCFF), Agricultural Research Center, Ministry of Agriculture, Giza, Egypt. The analyses were carried out at laboratories of RCFF.

\section{Ethical approval}

This experiment was performed according to all ethics and animal rights of Agriculture Research Center, Egypt.

\section{Housing and management}

The present study consisted of 160 Cobb 500 unsexed one-day-old broiler chicks with 40 gram (g) initial weight. The chickens were randomly assigned into four different groups, four replicates of 10 chickens each, and were housed in a semiclosed house in mesh wire-floored cages equipped with automatic drinkers and pan feeders. The chicks were kept under a similar veterinary control and management system in all treatments. The house temperature was maintained at $32^{\circ} \mathrm{C}$ for the first 5 days, and then gradually decreased to $24^{\circ} \mathrm{C}$ at the age of 21 days. The chickens were received continuous light for the first 24 hours, and then 23 hours light and one hour of darkness for the remainder of the experiment. All chicks were monitored for general health twice daily. Feed and water were offered ad-libitum throughout the experimental period.

\section{The experimental diets and design}

The experiment was designed in a 2 (levels of protein) $\times 2$ (levels of Citric Acid, CA) factorial design arrangement during starter (1-14 days old), grower (15-28 days old), and finisher (29-42 days old) periods. The experimental diets included the protein levels of $100 \%$ (optimal level) or $90 \%$ (low level) of the requirements, and the CA levels of 0 or $20 \mathrm{~g} / \mathrm{kg}$ diet. The experimental diets were formulated to meet the nutritional recommendations according to Cobb 500 guide with the exception of $\mathrm{CP}$ in low protein diets (Table 1).

\section{Broiler performance}

The chickens and diets in each pen were weighed weekly, and feed efficiency was adjusted for mortality on a pen basis. The Initial Body Weight (IBW) and Final Body Weight (FBW) of each period were used to calculate Body Weight Gain (BWG). Feed Intake (FI) was recorded at the end of each period during the experiment. Feed Conversion Ratio (FCR) was calculated according to the following equation:

$\mathrm{FCR}=\mathrm{FI}(\mathrm{g}) / \mathrm{BWG}(\mathrm{g})$

BWG, FI, and FCR were calculated cumulatively at the end of the experiment.

The mortality was daily recorded throughout the experiment period.

\section{Carcass measurements}

At the end of the experiment, eight chickens from each treatment with approximately similar body weight were chosen for carcass measurements. Prior to slaughter, the selected chicks were deprived of feed for eight hours, individually weighed, and then slaughtered. After complete bleeding, the chicks were plucked by dry-plucking, and their weights were recorded. Head and shanks were removed, then the chicks were eviscerated, and different organs (i.e., intestine, gizzard, lungs, spleen, liver, and heart) were separated. The carcass giblets (i.e., gizzard, liver, and heart), and organs related to the immune system (i.e., spleen, and bursa of Fabricius) were separately weighed.

The proportional weight of giblets or carcass (dressing, \%) to live weight was calculated using the following equations:

Giblets weight $(\%)=[\mathrm{GW} / \mathrm{LBW}] \times 100$

Dressing $(\%)=[\mathrm{DW} / \mathrm{LBW}] \times 100$

Where LBW denotes live body weight, GW refers to giblets weight, and DW is dressed weight

\section{Meat composition}

The carcass was stored in an airtight polyethylene bag at $-18^{\circ} \mathrm{C}$ for the later evaluation of the whole-body chemical composition (dry matter, CP, fat, and ash).

\section{Intestinal morphology}

Small intestines were immediately removed from slaughtered chickens, excised, and flushed with distilled water for content removal. Segments of $2 \mathrm{~cm}$ in length from the midpoint of the duodenum fixed in a $10 \%$ buffered formalin. The samples were evaluated in terms of the Villus Height (VH) and Width (VW), Crypt Depth (CD), Villus Height to Crypt Depth ratio (VH/CD). The surface area of the villus was calculated as the product of the height multiplied by the width (Allameh and Toghyani, 2019). 


\section{Bacteriological analysis of caecal content}

At the end of the experimental period, eight birds from each experimental group were selected and slaughtered for bacteriological analysis. The caecum from each chicken was removed aseptically and the contents were transferred into a sterile test tube. The samples of caecum contents were examined for caecum microflora, including Lactobacillus bacteria, E- coil, and Clostridium perfringens.

\section{Blood parameters}

At the time of slaughter, eight blood samples were collected from experimental groups. Commercial diagnostic kits (Diamond Diagnostics Company, Egypt) used to measure total protein, albumin, cholesterol, renal function, Aspartate aminotransferase (AST) and Alanine aminotransferase (ALT). The globulin concentration was calculated as the difference between total protein and albumin according to Coles (1974). Haemoglobin (Hgb) was measured as mentioned by Van Kampen and Zillstra (1983) and plasma glucose was analyzed based on Trinder's (1969) method. Hemoglobin A1c (HbA1c) values were determined using a Variant II Kit analyzer (Bio-Rad, Hercules, California, USA). Fructosamine was calculated according to the following equation (Cohen et al., 2003):

Fructosamine $=(\mathrm{HbA} 1 \mathrm{c}-1.61) \times 58.82$

\section{Statistical analysis}

The general linear model was employed for data analysis using SAS software (SAS Institute, USA, 2004). Duncan's multiple range test (Duncan, 1955) was performed to detect significant differences of means. The p-value less than 0.05 was considered statistically significant. The employed model was as following:

$\mathrm{Y}_{\mathrm{ij}}=\mu+\mathrm{P}_{\mathrm{i}}+\mathrm{C}_{\mathrm{j}}+(\mathrm{PC})_{\mathrm{ij}}+\mathrm{e}_{\mathrm{ij}}$

Where, $\mathrm{Y}_{\mathrm{ijis}}$ refers to the observation of the parameter measured, $\mu$ is overall mean, $\mathrm{P}_{\mathrm{i}}$ denotes the fixed effect of protein level, $\mathrm{C}_{\mathrm{j}}$ counts for the fixed effect of CA level, $(\mathrm{PC})_{\mathrm{ij}}$ is the fixed effect of interaction between levels of CP and CA, and $\mathrm{e}_{\mathrm{ij}}$ stands for a random error.

Table 1. Composition and calculated analysis of the experimental diets for broiler during starter (1-14 days old), grower (15-28 days old), and finisher (29-42 days old) periods at the Poultry Research Unit, Giza, Egypt

\begin{tabular}{|c|c|c|c|c|c|c|c|c|c|c|c|c|}
\hline \multirow{2}{*}{$\begin{array}{l}\text { Ingredient } \\
\text { Yellow Corn } \\
(8.2 \% \mathrm{CP})\end{array}$} & \multicolumn{4}{|c|}{ Starter ( 1-14days old) } & \multicolumn{4}{|c|}{ Grower (15-28days old) } & \multicolumn{4}{|c|}{ Finishers (29- 42days old) } \\
\hline & 56.46 & 53.23 & 61.30 & 57.89 & 59.60 & 56.00 & 65.07 & 61.67 & 63.92 & 60.37 & 69.04 & 65.34 \\
\hline $\begin{array}{l}\text { Soybean Meal } \\
(44.5 \% \mathrm{CP})\end{array}$ & 31.66 & 31.557 & 29.00 & 29.00 & 31.85 & 32.47 & 27.30 & 27.30 & 27.50 & 27.90 & 23.40 & 23.95 \\
\hline $\begin{array}{l}\text { Corn Gluten Meal } \\
(59.4 \% \mathrm{CP})\end{array}$ & 6.00 & 6.50 & 4.04 & 4.50 & 2.00 & 2.00 & 1.65 & 2.082 & 1.55 & 1.62 & 1.00 & 1.00 \\
\hline Vegetable Oil & 1.82 & 2.75 & 1.55 & 2.50 & 2.75 & 3.83 & 2.05 & 3.05 & 3.467 & 4.60 & 2.85 & 4.00 \\
\hline $\begin{array}{l}\text { Vitamins \& } \\
\text { Minerals premix* }\end{array}$ & 0.30 & 0.30 & 0.30 & 0.30 & 0.30 & 0.30 & 0.30 & 0.30 & 0.30 & 0.30 & 0.30 & 0.30 \\
\hline Common Salt & 0.40 & 0.40 & 0.40 & 0.40 & 0.40 & 0.40 & 0.40 & 0.40 & 0.40 & 0.40 & 0.40 & 0.40 \\
\hline L-lysine-HCl & 0.17 & 0.17 & 0.25 & 0.25 & 0.10 & 0.09 & 0.205 & 0.21 & 0.11 & 0.11 & 0.23 & 0.23 \\
\hline DL-Methionine & 0.10 & 0.1 & 0.111 & 0.111 & 0.125 & 0.125 & 0.145 & 0.145 & 0.12 & 0.12 & 0.15 & 0.15 \\
\hline $\begin{array}{l}\text { Di-calcium } \\
\text { Phosphate }\end{array}$ & 2.10 & 2.05 & 2.107 & 2.107 & 1.96 & 1.90 & 1.90 & 1.91 & 1.75 & 1.75 & 1.70 & 1.70 \\
\hline Limestone & 0.91 & 0.86 & 0.86 & 0.86 & 0.83 & 0.80 & 0.90 & 0.85 & 0.80 & 0.75 & 0.85 & 0.85 \\
\hline Choline chloride & 0.083 & 0.083 & 0.083 & 0.083 & 0.083 & 0.083 & 0.083 & 0.083 & 0.083 & 0.083 & 0.083 & 0.083 \\
\hline Citric acid & 0.00 & 2.00 & 0.00 & 2.00 & 0.00 & 2.00 & 0.00 & 2.00 & 0.00 & 2.00 & 0.00 & 2.00 \\
\hline Total & 100 & 100 & 100 & 100 & 100 & 100 & 100 & 100 & 100 & 100 & 100 & 100 \\
\hline
\end{tabular}

Composition, calculated ${ }^{* *}$

\begin{tabular}{|c|c|c|c|c|c|c|c|c|c|c|c|c|}
\hline $\begin{array}{l}\text { Metaboizable E } \\
\text { k.cal/kg }\end{array}$ & 3000 & 3000 & 3003 & 3000 & 3053 & 3053 & 3052 & 3053 & 3154 & 3159 & 3153 & 3155 \\
\hline Crude protein $\%$ & 22.3 & 22.3 & 20.3 & 20.3 & 20.3 & 20.2 & 18.5 & 18.5 & 18.4 & 18.3 & 16.7 & 16.6 \\
\hline Calcium \% & 0.93 & 0.90 & 0.90 & 0.90 & 0.86 & 0.84 & 0.86 & 0.85 & 0.79 & 0.77 & 0.78 & 0.79 \\
\hline $\begin{array}{l}\text { Available } \\
\text { phosphors \% }\end{array}$ & 0.46 & 0.45 & 0.46 & 0.46 & 0.44 & 0.43 & 0.42 & 0.42 & 0.40 & 0.39 & 0.38 & 0.38 \\
\hline Lysine \% & 1.23 & 1.22 & 1.23 & 1.22 & 1.13 & 1.13 & 1.12 & 1.12 & 1.03 & 1.03 & 1.05 & 1.05 \\
\hline Methionine $\%$ & 0.49 & 0.49 & 0.46 & 0.46 & 0.46 & 0.46 & 0.45 & 0.45 & 0.43 & 0.42 & 0.43 & 0.43 \\
\hline Methionine+ & 0.86 & 0.86 & 0.81 & 0.81 & 0.80 & 0.80 & 0.77 & 0.76 & 0.74 & 0.74 & 0.72 & 0.72 \\
\hline
\end{tabular}

CP: Crude Protein.*Vitamin and mineral premix each 2Kg contains: Vitamin A $10000000 \mathrm{IU}$, Vitamin $\mathrm{D}_{3} 3000000 \mathrm{IU}, \mathrm{Vitamin} \mathrm{E} 25000 \mathrm{mg}$, Vitamin K 2000 $\mathrm{mg}$, Vitamin $\mathrm{B}_{1} 1500 \mathrm{mg}$; Vitamin $\mathrm{B}_{2} 5000 \mathrm{mg}$, Vitamin $\mathrm{B}_{6} 1500 \mathrm{mg}$, Vitamin $\mathrm{B}_{12} 15000 \mathrm{mcg}$, Niacin $30000 \mathrm{mg}$, folic acid $1000 \mathrm{mg}$, Pantothenic acid $10000 \mathrm{mg}$, Biotin $75000 \mathrm{mcg}$, copper $50000 \mathrm{mg}$, iron $40000 \mathrm{mg}$, manganese $60000 \mathrm{mg}$, zinc (Oxide) $60000 \mathrm{mg}$, iodine $1000 \mathrm{mg}$, selenium $300 \mathrm{mg}$, cobalt $200 \mathrm{mg}$, BHT (Antioxidant) $250 \mathrm{mg}$ and Carrier: Calcium Carbonate up to $2 \mathrm{Kg}$.**Values were calculated from the data according to NRC (1994). Calculated values of crude protein are based on determined values for corn $(8.2 \% \mathrm{CP})$, soybean meal $(44.5 \% \mathrm{CP})$, and corn gluten meal $(59.4 \% \mathrm{CP})$.

To cite this paper: Abd-Elsamee MO, Fathy Abbas Motawe H, Maher Selim M and Ramadan Elsherif HM (2020). Effect of Different Dietary Crude Protein Levels and Citric Acid on Broiler Chickens' Performance, Carcass Characteristics, Intestinal Morphology, and Blood Components. World Vet. J., 10 (3): 362-374. DOI: https://dx.doi.org/10.36380/scil.2020.wvj45 


\section{RESULTS AND DISCUSSION}

\section{Growth performance}

The effect of adding CA in low protein broiler diet on FI, BWG, and FCR at day 42 of age is presented in table 2. The reduction in dietary CP percentage could significantly increase FI, while BWG and FCR were negatively affected. Although CA addition had no significant effect on FI, it could significantly improve BWG and FCR values ( $\mathrm{p} \leq 0.05)$. The best BWG and FCR values were recorded for the chickens fed 100\% CP (optimal level) with the addition of CA. The low protein diet supplemented with CA showed improvements in BWG and FCR of chickens, compared to those fed a low protein diet without CA addition. Regarding citric acid, the BWG and FCR values ( $2312 \mathrm{~g}$ and 1.59 , respectively) in chickens receiving a low protein with CA diet were as ameliorated as those fed the required CP (2314 g and 1.57, respectively). Consequently, significant differences were observed in the investigated treatments due to $\mathrm{CP}$ and $\mathrm{CA}$ interaction.

The obtained results of the present study addressing feed consumption elevation due to low protein levels were in line with the results obtained by Aletor et al. (2000) and Barekatain et al. (2019) indicating increased FI caused by low protein use in the broiler diet. However, Roy et al. (2010) and Park and Kim (2019) stated that feed consumption of broilers was not significantly influenced by dietary protein level. On the other hand, Malomo et al. (2013) and Allameh and Toghyani (2019) concluded that the FI of broiler chickens decreased significantly as the CP level reduced. Several reasons could explain the increase in feed consumption for the low protein diets fed with broilers, including the effect of CP on the appetite of fed broilers (Srilatha et al., 2018), deficiency of some critical amino acids, and the differences in the digestibility of amino acids in the diets (Kamran et al., 2010), and the birds might increase the feed intake to get their CP requirements (Selim, 2015; Belloir et al., 2017 and Mahmoud et al., 2017).

Several studies reported the inferior effects of low dietary protein on broiler growth performance (Hernández et al., 2012; Folorunso et al., 2014 and Liu et al., 2017). In the same vein, Allameh and Toghyani (2019) concluded that the weight of broiler chickens significantly decreased when the dietary CP reduced from $20.4 \%$ to $17.9 \%$. Moreover, they concluded that feeding $85 \%$ of $\mathrm{CP}$ requirements had negative effects on the daily weight gain of broilers. Recently, Hilliar et al. (2020) and Macelline et al. (2020) concluded that birds were fed low protein diets had a low BWG, compared to chicks that were fed high protein diets. However, Tarsewics et al. (2006) found that diets with different protein levels had no significant effect on the BWG of birds.

The FCR results of the current study were in accordance with the findings of a study conducted by Gheorghe (2013) concluding that the highest FCR value in a group fed sub-optimal protein diet might be due to the increase in the feed consumption with low body weight gain. Selim (2015) stated that the different amounts of feed consumed on a 22\% CP diet could result in less rapid passage of feed in the intestine, compared to a diet with low CP (20\%) with a high rapid passage of consumed feed. This issue could result in a decrease in nutrients utilization, which could have a negative effect on the BWG. The results of the current study suggested that CA had no contributory role in FI which was also supported by Abdel-Fattah et al. (2008) and Dehghani-Tafti and Jahanian (2016). On the contrary, Haque et al. (2010) reported that the CA had a significant effect on the FI of broiler chickens.

More notably, the outcomes of the current study underline the improvement of BW and FCR values due to the use of CA. In the same vein, Panda et al. (2009) asserted that FCR was reduced in treatments with organic acids and had no effect on FI. Moreover, Islam et al. (2011) reported that birds fed CA diets had high body weights of 2.2, 4.68, and $5.03 \%$ for the $0.25,0.75$, and $1.25 \%$ of CA groups, respectively, compared to the control birds. In addition, Nourmohammadi and Khosravinia (2015) concluded that 3\% of CA in the broiler diet led to an increase in BWG around 4.16\%. Lakshmi et al. (2016) announced that adding CA (2\%) to the broiler diet improved the broiler performance by 10\%. Nourmohammadi and Khosravinia (2015) stated that adding CA (3\%) had positive effects on BWG, FI, and FCR of broilers since it could ameliorate nutrients digestibility as a result of proper intestinal conditions. However, Biggs and Parsons (2008) found that using 3\% of CA had no significant effect on the broiler's performance.

\section{Carcass measurements}

The effects of adding CA to a low protein broiler diet on the whole body chemical composition and abdominal fat percentage are shown in table 3. A significant $(\mathrm{p}<0.05)$ increase was found in DM, fat, and abdominal fat percentage due to a low protein level, compared to the optimal CP level. On the other hand, it should be mentioned that the protein level had no significant effect on $\mathrm{CP}$ and ash percentage regarding the whole body. Citric acid improved the chemical composition of meat (DM, Fat, and $\mathrm{CP} \%$ ) and abdominal fat percentage compared to non-supplemented groups. The protein level and CA interactions showed significant differences $(\mathrm{p}<0.05)$ in $\mathrm{DM}, \mathrm{CP}$, fat, and abdominal fat percentage. Citric acid added to a low protein diet significantly $(\mathrm{p}<0.05)$ decreased fat and abdominal fat and increased $\mathrm{CP}$ percentage in broiler carcass. 
The negative effect of sub-optimal dietary $\mathrm{CP}$ on carcass composition in the present study was in agreement with the findings of studies performed by Aletor et al. (2000); Namroud et al. (2008); Sigolo et al. (2017), and Srilatha et al. (2018). Likewise, Javaid et al. (2012) construed the effect of dietary protein on meat DM through the depression of liver lipogenesis leading to a reduction in fat deposition in the muscles and subsequently a reduction in the DM of the meat. Furthermore, the negative correlation between protein levels and fat deposition could initially be due to the increase in feed consumption for birds to meet growth requirements, as a response to any nutrient deficiency (Kamran, 2010) could increase fat deposition (Gous et al., 1990). Second, high Metabolic Energy to CP ratio in a low protein diet promotes lipogenesis (Sigolo et al., 2017) because of the more energy intake per unit of CP intake (Srilatha et al., 2018). Third, the increase of abdominal fat by low CP diets could be due to the reducing in the heat increment which demands the transamination and deamination of superfluous amino acids. Therefore, higher energy was deposited as abdominal fat (Namroud et al., 2008 and Allameh and Toghyani, 2019).

In agreement with our results, Abdel-Fattah et al. (2008) found that 3\% of CA dietary supplementation could significantly decrease the abdominal fat. Furthermore, Samanta et al. (2008) stated that the mixture of organic acids induced non-significant increase in meat CP and a decrease in meat fat. However, Dehghani-Tafti and Jahanian (2016) reported that organic acids had no significant effect on the abdominal fat deposition. The effects of CA on the percentage of fat and abdominal fat could be due to the role of dietary organic acids in inhibiting glycolysis and stimulating glycogenesis (Sabour et al., 2019).

Table 4 summarized the effects of adding CA to a low protein broiler diet on the percentage of dressing and the relative weight of the lymphoid organs (Bursa and Spleen). Protein levels had no significant effect on the relative weight of lymphoid organs. However, the low protein level decreased the dressing (from $74.93 \%$ for optimal protein levels to $73.86 \%$ for low protein levels). The percentage of dressing and relative weight of bursa was significantly higher in groups supplemented with CA. The results showed that adding CA to a low protein diet improved the percentage of dressing percentage and had no significant effect on the relative weight of bursa and spleen. The highest value for the percentage of dressing $(75.86 \%)$ was recorded by a diet containing $100 \%$ of required CP + CA while the lowest value (73\%) was for the group fed on $90 \%$ of required CP- CA. The addition of CA to a low protein diet had improved the percentage of dressing to be approximately the same as the control group. The negative effects of the low protein diets on dressing percentage in the present study supported by Selim (2015) and Dehghani-Tafti and Jahanian (2016), who found that reducing dietary $\mathrm{CP}$ levels decreased the carcass yield of chickens.

The percentage of dressing was significantly higher in CA groups. The findings of the current study are in line with the results of the previous studies (Islam et al., 2011; Dehghani-Tafti and Jahanian, 2016 and Sultan et al., 2018). In the current study, the results showed that the relative weight of bursa of Fabricius and the spleen are not affected by low protein diets. However, CA resulted in the improved relative weight of bursa of Fabricius, there were no differences regarding the spleen percentage. The spleen and bursa of Fabricius are a part of the immunity system (Abdel-Fattah et al., 2008). An immunological response could be expected via the improved in relative lymphoid organs (Katanbaf et al., 1989). The lack of protein levels effect on lymphoid organs was agreed with Golian et al. (2010), while Jahanian (2009) and Barekatain et al. (2019) found that reducing dietary CP had decreased the weights of lymphoid organs.

\section{Intestinal morphology}

The effect of adding $\mathrm{CA}$ to a low protein broiler diets on $\mathrm{VH}, \mathrm{VW}, \mathrm{CD}, \mathrm{VH} / \mathrm{CD}$ ratio, and absorption area is presented in table 5. The current study showed that low dietary protein had a significant effect on the intestinal morphology. The decrease in dietary CP content significantly decreased VH, VW, and VW/CD, and absorption area, compared to an optimal protein level. Citric acid addition improved $(\mathrm{p} \leq 0.05) \mathrm{VH}, \mathrm{VH} / \mathrm{CD}$, and increased absorption surface. The interaction between protein level and CA showed that the chickens' group fed on CP $100 \%+\mathrm{CA}$ had the highest values for $\mathrm{VH}, \mathrm{VW}, \mathrm{VH} / \mathrm{CD}$, and absorption area, while CP 90\% - CA recorded the lowest values. The intestinal morphology parameters of the chickens' group fed low dietary protein (CP90) rose to a comparable level to that of the required protein fed (CP100) when CA was included.

Khosravinia et al. (2015) suggested that the increase in digestion and absorption was correlated with the increase in the $\mathrm{VH} / \mathrm{CD}$ ratio. As a result, the ratio was a marker of the digestive capacity of the small intestine (Allameh and Toghyani, 2019).

The decrease in dietary $\mathrm{CP}$ content caused a significant decrease in $\mathrm{VH}, \mathrm{VW}, \mathrm{VW} / \mathrm{CD}$, and absorption area, which lend support to a study conducted by Mahmoud et al. (2017) reporting a slight decrease in the VH of broilers fed with $98 \%$ of required CP, compared to $100 \%$ of required CP. Moreover, Allameh and Toghyani (2019) stated that the reduction of dietary $\mathrm{CP}(85 \%$ of required $\mathrm{CP}$ ) resulted in a negative impact on VH in the jejunum. However, Laudadio et al. (2012) found an increase in VH in the duodenum of broilers that consumed low dietary protein (20.5\% CP), compared to those consumed high dietary protein $(22.5 \% \mathrm{CP})$. 
The improvement of $\mathrm{VH}, \mathrm{VH} / \mathrm{CD}$, and the enlargement in villus surfaces area of the broilers fed diets supplemented with CA in the present study was also observed by Khosravinia et al. (2015), who found 3\% dietary CA increased VH of the broiler. Moreover, Paul et al. (2007) and Samanta et al. (2010) stated that the use of acidifiers in the chickens' diet could increase VH. The improvement in VH resulted in an enlarged surface area for nutrients absorption and thus to higher growth performance (Mohammadagheri et al., 2016).

The amelioration of body gain and FCR by dietary supplementation with CA could be due to the improvement in VH and enlarged absorptive surface area (Dehghani and Jahanian, 2012). The positive influence of organic acids on VH and $\mathrm{VH} / \mathrm{CD}$ ratios suggested that CA might improve the rate of nutrient absorption (Nourmohammadi and Afzali, 2013).

\section{Bacteriological analysis of caecal content}

The effect of adding CA to a low protein broiler diets on the cecum microbial counts $\left(\log ^{-1} \mathrm{CFU} / \mathrm{g}\right)$, including Lactobacillus, E. coli, and Clostridium perfringens is shown in table 6. Dietary protein level had no significant effect on cecum microbial counts. However, CA addition had significantly improved Lactobacillus counts and reduced E. coli and Clostridium perfringens counts. The interaction between protein and CA showed significant differences in the bacterial populations (Lactobacillus, Escherichia coli, and Clostridium perfringens). Citric acid caused a significant increase in Lactobacillus, compared to non-supplemented groups. Furthermore, smaller numbers of E- coil and Clostridium perfringens were attributed to CA addition.

The obtained results of the current study addressing the effect of the protein levels on cecum microbial counts were in line with the findings of a study carried out by Ravangard et al. (2017), in which they reported that there were no significant differences in Lactobacillus and Escherichia bacteria counts in broiler chickens fed on the either low or required dietary protein levels.

Citric acid supplementation resulted in a significant improvement in Lactobacillus counts and reduction in E. coli and Clostridium perfringens counts, which resemble the results of EL-Afifi et al. (2001) and Ghazalah et al. (2011). Furthermore, Ahmad et al. (2018) found that CA (40g/kg) increased beneficial (Lactobacillus) bacteria, while reduced E. coli count, compared to the control group. Lactobacillaceae have an important role in host metabolism (Zhu et al., 2015). Similar to the findings of the current study, Cesare et al. (2019) observed a positive relation between Lactobacillaceae and amelioration of FCR.

\section{Blood Parameters}

The effect of adding CA and dietary protein level on blood components of broilers is presented in table 7 . The protein level showed no significant effect on glucose, uric acid (UA), and AST, while the low protein level led to a decrease $(\mathrm{p}<0.05)$ in albumin, total protein, and increase in hemoglobin A1c, fructosamine (glycation indicators), and cholesterol. Citric acid addition was increased albumin and decreased hemoglobin A1c, fructosamine, cholesterol, and uric acid. The results showed that the interaction between CP level and CA had no effect on blood glucose, hemoglobin, UA, and AST. The optimal protein level groups recorded the highest values $(\mathrm{p}<0.05)$ for total protein, albumin, and globulin, and lowest values for hemoglobin A1C, fructosamine, and cholesterol.

The results of the present study related to the effect of the CP level on the blood parameters were in accordance with the findings of Swennen et al. (2005), Kamran et al. (2010), and Mohamed et al. (2012) concluding that the level of dietary protein did not alter glucose concentration. In addition, Alam et al. (2004) and Mohamed et al. (2012) indicated that the dietary protein level had no significant effect on the haemoglobin concentration of broilers. In addition, Mohamed et al. (2012) stated that the dietary protein caused only the globin section of the haemoglobin to increase with no effect on the haem section.

A low level of albumin is related to the glycation of plasma proteins and HbAlc (Bhonsle et al., 2012). According to Honma et al. (2017), protein levels in chicken diets could modify blood albumin levels and low dietary protein could increase the glycated amino acids in chicken plasma. Haemoglobin A1c reflects non-enzymatic glycosylation and fructosamine examined for glycation, associated primarily with albumin (Anguizola et al., 2013). The In vivo experiment conducted by Bhonsle et al. (2012) indicated that blood albumin could control the plasma protein glycation. Moreover, Tiwari et al. (2015) found an inverse correlation between plasma albumin and HbA1c.

The present results for CA were consistent with those obtained by Abdel-Fattah et al. (2008) indicating that dietary acidifiers (e.g. CA, acetic acid, and lactic acid) significantly decreased total lipids, and cholesterol, in the blood. 
Furthermore, Al-Saad et al. (2014) reported that there was no effect of organic acid in the blood hemoglobin and glucose. Ur Rehman et al. (2016) found that organic acids had no significant effect on the hemoglobin of broiler chickens. In the same vein, Nosrati et al. (2017) concluded that organic acid had no effect on the blood total protein and glucose of the broiler.

The positive effects of dietary protein and CA on the glycation reaction may be due to its effects on albumin levels. Moreover, the dietary protein might alter plasma amino compounds (Honma et al., 2017). In the study performed by Ali et al. (2013), it was found that there was a correlation between intestinal microflora and HbA1c, which could explain the effect of $\mathrm{CA}$ on $\mathrm{HbA1c}$ through its effect on the intestinal microflora. More studies are needed to clarify the correlation between $\mathrm{CA}$, intestinal microflora, and glycation in poultry.

Table 2. The effect of low protein broiler diets supplemented with citric acid on broilers' performance during 1-42 days of age at the Poultry Research Unit, Giza, Egypt.

\begin{tabular}{|c|c|c|c|c|}
\hline \multicolumn{2}{|l|}{ Treatments } & \multicolumn{3}{|c|}{ Parameters } \\
\hline $\mathrm{CP}$ & CA & $\begin{array}{c}\text { Feed intake } \\
\text { (g/chicken) }\end{array}$ & $\begin{array}{c}\text { BW gain } \\
\text { (g/chicken) }\end{array}$ & $\begin{array}{c}\text { FCR } \\
\text { (g feed: g gain) }\end{array}$ \\
\hline \multicolumn{5}{|c|}{ Main effect of $\mathbf{C P}$} \\
\hline $100 \%$ & ----- & $3631^{\mathrm{b}}$ & $2376^{\mathrm{a}}$ & $1.53^{\mathrm{b}}$ \\
\hline $90 \%$ & ---- & $3682^{\mathrm{a}}$ & $2278^{\mathrm{b}}$ & $1.62^{\mathrm{a}}$ \\
\hline \multicolumn{5}{|c|}{ Main effect of CA } \\
\hline----- & $0 \%$ & 3655 & $2280^{\mathrm{b}}$ & $1.60^{\mathrm{a}}$ \\
\hline ----- & $2 \%$ & 3658 & $2375^{\mathrm{a}}$ & $1.54^{\mathrm{b}}$ \\
\hline \multicolumn{5}{|c|}{ CP×CA effect } \\
\hline $100 \%$ & $0 \%$ & $3629^{b}$ & $2314^{\mathrm{b}}$ & $1.57^{\mathrm{b}}$ \\
\hline $100 \%$ & $2 \%$ & $3633^{b}$ & $2438^{\mathrm{a}}$ & $1.49^{c}$ \\
\hline $90 \%$ & $0 \%$ & $3681^{\mathrm{a}}$ & $2245^{\mathrm{c}}$ & $1.64^{\mathrm{a}}$ \\
\hline $90 \%$ & $2 \%$ & $3683^{\mathrm{a}}$ & $2312^{\mathrm{b}}$ & $1.59^{\mathrm{b}}$ \\
\hline SEM & & 7.57 & 16.43 & 0.01 \\
\hline \multicolumn{5}{|l|}{ p-value } \\
\hline $\mathrm{CP}$ & & $<0.0001$ & 0.0009 & $<0.0001$ \\
\hline $\mathrm{CA}$ & & 0.38 & 0.001 & 0.001 \\
\hline $\mathrm{CP} \times \mathrm{CA}$ & & $<0.0001$ & $<0.0001$ & $<0.0001$ \\
\hline
\end{tabular}

Means designated with the same letter within the same column are not significantly different at 0.05 level of probability. The beginning weight was 40g. BWG: Body weight gain, FCR: Feed conversion ratio, CP: Crude protein, CA: Citric acid, SEM: Standard error of the mean.

Table 3. The effect of low protein broiler diets supplemented with citric acid on broilers' whole body composition and abdominal fat percentage at 42 days of age at the Poultry Research Unit, Giza, Egypt.

\begin{tabular}{|c|c|c|c|c|c|c|}
\hline \multicolumn{2}{|c|}{ Treatments } & \multicolumn{5}{|c|}{ Parameters } \\
\hline \multirow{2}{*}{$\mathbf{C P}$} & \multirow{2}{*}{$\mathbf{C A}$} & \multicolumn{4}{|c|}{ Whole-body composition (\%) } & \multirow{2}{*}{ Abdominal fat (\%) } \\
\hline & & Dry matter & Fat & Protein & Ash & \\
\hline \multicolumn{7}{|c|}{ Main effect of CP } \\
\hline $100 \%$ & --------- & $27.05^{\mathrm{b}}$ & $7.06^{\mathrm{b}}$ & 22.55 & 4.13 & $1.16^{\mathrm{b}}$ \\
\hline $90 \%$ & -------- & $27.76^{\mathrm{a}}$ & $8.26^{\mathrm{a}}$ & 22.39 & 4.05 & $1.39^{\mathrm{a}}$ \\
\hline \multicolumn{7}{|c|}{ Main effect of CA } \\
\hline --------- & 0.00 & $27.11^{\mathrm{b}}$ & $8.57^{\mathrm{a}}$ & $21.89^{\mathrm{b}}$ & 4.11 & $1.43^{\mathrm{a}}$ \\
\hline --------- & 2.00 & $27.70^{\mathrm{a}}$ & $6.75^{\mathrm{b}}$ & $23.05^{\mathrm{a}}$ & 4.08 & $1.13^{\mathrm{b}}$ \\
\hline \multicolumn{7}{|c|}{ CP $\times$ CA effect } \\
\hline $100 \%$ & $0 \%$ & $26.50^{\mathrm{b}}$ & $7.60^{\mathrm{b}}$ & $21.83^{c}$ & 4.29 & $1.32^{\mathrm{b}}$ \\
\hline $100 \%$ & $2 \%$ & $27.59^{\mathrm{a}}$ & $6.52^{\mathrm{c}}$ & $23.27^{\mathrm{a}}$ & 3.97 & $1.00^{\mathrm{d}}$ \\
\hline $90 \%$ & $0 \%$ & $27.71^{\mathrm{a}}$ & $9.54^{\mathrm{a}}$ & $21.95^{\mathrm{c}}$ & 3.92 & $1.53^{\mathrm{a}}$ \\
\hline $90 \%$ & $2 \%$ & $27.80^{\mathrm{a}}$ & $6.98^{\mathrm{cb}}$ & $22.82^{\mathrm{b}}$ & 4.18 & $1.25^{\mathrm{c}}$ \\
\hline SEM & & 0.12 & 0.98 & 0.43 & 0.01 & 0.03 \\
\hline \multicolumn{7}{|l|}{ p-value } \\
\hline $\mathrm{CP}$ & & 0.002 & 0.02 & 0.78 & 0.64 & 0.0001 \\
\hline $\mathrm{CA}$ & & 0.01 & 0.0002 & 0.0011 & 0.79 & $<0.0001$ \\
\hline $\mathrm{CP} \times \mathrm{CA}$ & & $<0.0001$ & $<0.0001$ & $<0.0001$ & 0.38 & $<0.0001$ \\
\hline
\end{tabular}

Means designated with the same letter within the same column are not significantly different at 0.05 level of probability. CP: Crude protein, CA: Citric acid, SEM: Standard error of the mean 
Table 4. The effect of low protein broiler diets supplemented with citric acid on the percentage of dressing and relative weight of lymphoid organs at 42 days of age at the Poultry Research Unit, Giza, Egypt.

\begin{tabular}{|c|c|c|c|c|}
\hline \multicolumn{2}{|l|}{ Treatments } & \multicolumn{3}{|c|}{ Parameters } \\
\hline \multirow{2}{*}{$\mathbf{C P}$} & \multirow{2}{*}{ CA } & \multirow{2}{*}{ Dressing $(\%)$} & \multicolumn{2}{|c|}{ Relative weight of lymphoid organs (\%) } \\
\hline & & & Spleen & Bursa \\
\hline \multicolumn{5}{|c|}{ Main effect of CP } \\
\hline $100 \%$ & --------- & $74.93^{\mathrm{a}}$ & 0.14 & 0.22 \\
\hline $90 \%$ & -------- & $73.86^{\mathrm{b}}$ & 0.13 & 0.21 \\
\hline \multicolumn{5}{|c|}{ Main effect of CA } \\
\hline ---------- & 0.00 & $73.50^{\mathrm{b}}$ & 0.12 & $0.19^{\mathrm{b}}$ \\
\hline ---------- & $2 \%$ & $75.29^{\mathrm{a}}$ & 0.14 & $0.24^{\mathrm{a}}$ \\
\hline \multicolumn{5}{|c|}{ CP $\times$ CA effect } \\
\hline $100 \%$ & $0 \%$ & $74.00^{\mathrm{b}}$ & 0.13 & 0.20 \\
\hline $100 \%$ & $2 \%$ & $75.86^{\mathrm{a}}$ & 0.14 & 0.24 \\
\hline $90 \%$ & $0 \%$ & $73.00^{\mathrm{c}}$ & 0.11 & 0.18 \\
\hline $90 \%$ & $2 \%$ & $74.72^{\mathrm{b}}$ & 0.14 & 0.23 \\
\hline SEM & & 0.22 & 0.01 & 0.01 \\
\hline \multicolumn{5}{|l|}{ P-value } \\
\hline $\mathrm{CP}$ & & 0.01 & 0.10 & 0.80 \\
\hline $\mathrm{CA}$ & & $<0.0001$ & 0.13 & 0.007 \\
\hline $\mathrm{CP} \times \mathrm{CA}$ & & $<0.0001$ & 0.50 & 0.058 \\
\hline
\end{tabular}

Means designated with the same letter within the same column are not significantly different at 0.05 level of probability. CP: Crude Protein, CA: Citric Acid, SEM: Standard Error of the Mean

Table 5. The effect of low protein broiler diets supplemented with citric acid on intestinal morphology at 42 days of age at the Poultry Research Unit, Giza, Egypt.

\begin{tabular}{|c|c|c|c|c|c|c|}
\hline \multirow{2}{*}{$\begin{array}{l}\text { Treatments } \\
\mathrm{CP}\end{array}$} & \multirow[b]{2}{*}{ CA } & \multicolumn{5}{|c|}{ Parameters } \\
\hline & & Villus height $(\mu \mathrm{m})$ & $\begin{array}{c}\text { Villus Width } \\
(\mu \mathrm{m})\end{array}$ & $\begin{array}{c}\text { Crypt depth } \\
(\mu \mathrm{m})\end{array}$ & VH/CD & $\begin{array}{c}\text { Absorption } \\
\text { area/1000 }\end{array}$ \\
\hline \multicolumn{7}{|c|}{ Main effect of CP } \\
\hline $100 \%$ & -------- & $1905^{\mathrm{a}}$ & $157.33^{\mathrm{a}}$ & 152.13 & $12.57^{\mathrm{a}}$ & $300.00^{\mathrm{a}}$ \\
\hline $90 \%$ & ------- & $1759^{b}$ & $132.72^{\mathrm{b}}$ & 153.46 & $11.58^{\mathrm{b}}$ & $233.45^{\mathrm{b}}$ \\
\hline \multicolumn{7}{|c|}{ Main effect of CA } \\
\hline ------- & 0.00 & $1770^{\mathrm{b}}$ & 142.56 & 154.89 & $11.53^{\mathrm{b}}$ & $252.30^{\mathrm{b}}$ \\
\hline -------- & $2 \%$ & $1894^{\mathrm{a}}$ & 147.49 & 150.70 & $12.62^{\mathrm{a}}$ & $279.39^{\mathrm{a}}$ \\
\hline \multicolumn{7}{|c|}{ CP $\times$ CA effect } \\
\hline $100 \%$ & $0 \%$ & $1858^{\mathrm{b}}$ & $155.31^{\mathrm{a}}$ & 151.74 & $12.37^{\mathrm{a}}$ & $288.56^{\mathrm{b}}$ \\
\hline $100 \%$ & $2 \%$ & $1952^{\mathrm{a}}$ & $159.34^{\mathrm{a}}$ & 152.51 & $12.77^{\mathrm{a}}$ & $311.03^{\mathrm{a}}$ \\
\hline $90 \%$ & $0 \%$ & $1682^{\mathrm{c}}$ & $129.80^{\mathrm{b}}$ & 158.04 & $10.56^{\mathrm{b}}$ & $218.30^{\mathrm{d}}$ \\
\hline $90 \%$ & $2 \%$ & $1835^{\mathrm{b}}$ & $135.64^{b}$ & 148.88 & $12.47^{\mathrm{a}}$ & $248.90^{\mathrm{c}}$ \\
\hline SEM & & 14.53 & 2.09 & 1.5 & 0.18 & 5.48 \\
\hline \multicolumn{7}{|l|}{ p-value } \\
\hline $\mathrm{CP}$ & & $<0.0001$ & $<0.0001$ & 0.67 & 0.004 & 0.01 \\
\hline $\mathrm{CA}$ & & 0.002 & 0.22 & 0.17 & 0.001 & $<0.0001$ \\
\hline $\mathrm{CP} \times \mathrm{CA}$ & & $<0.0001$ & $<0.0001$ & 0.21 & $<0.0001$ & $<0.0001$ \\
\hline
\end{tabular}

Means designated with the same letter within the same column are not significantly different at 0.05 level of probability. VH: Villus height, CD: Crypt depth, CP: Crude protein, CA: Citric acid, SEM: Standard error of the mean.

Table 6. The effect of low protein broiler diets supplemented with citric acid on caecal bacterial counts

\begin{tabular}{|c|c|c|c|c|}
\hline \multicolumn{2}{|c|}{ Treatments } & \multicolumn{3}{|c|}{ Parameters } \\
\hline $\mathbf{C P}$ & CA & Lactobacillus & Escherichia coli & $\begin{array}{l}\text { Clostridium } \\
\text { perfringens }\end{array}$ \\
\hline \multicolumn{5}{|c|}{ Main effect of CP } \\
\hline $100 \%$ & -------- & 3.49 & 7.34 & 11.32 \\
\hline $90 \%$ & -------- & 3.36 & 7.59 & 10.92 \\
\hline \multicolumn{5}{|c|}{ Main effect of CA } \\
\hline ------- & 0.00 & $3.16^{\mathrm{b}}$ & $7.66^{\mathrm{a}}$ & $11.54^{\mathrm{a}}$ \\
\hline ------- & $2 \%$ & $3.71^{\mathrm{a}}$ & $7.28^{\mathrm{b}}$ & $10.71^{\mathrm{b}}$ \\
\hline \multicolumn{5}{|c|}{ CP $\times C A$ effect } \\
\hline $100 \%$ & $0 \%$ & $3.17^{\mathrm{c}}$ & $7.55^{\mathrm{ab}}$ & $11.63^{\mathrm{a}}$ \\
\hline $100 \%$ & $2 \%$ & $3.82^{\mathrm{a}}$ & $7.14^{\mathrm{c}}$ & $11.02^{\mathrm{c}}$ \\
\hline $90 \%$ & $0 \%$ & $3.14^{\mathrm{c}}$ & $7.77^{\mathrm{a}}$ & $11.45^{\mathrm{b}}$ \\
\hline $90 \%$ & $2 \%$ & $3.59^{\mathrm{b}}$ & $7.42^{\mathrm{bc}}$ & $10.39^{\mathrm{d}}$ \\
\hline SEM & & 0.09 & 0.08 & 0.14 \\
\hline \multicolumn{5}{|l|}{ p-value } \\
\hline $\mathrm{CP}$ & & 0.46 & 0.12 & 0.17 \\
\hline $\mathrm{CA}$ & & $<0.0001$ & 0.009 & 0.0003 \\
\hline $\mathrm{CP} \times \mathrm{CA}$ & & $<0.0001$ & 0.01 & $<0.0001$ \\
\hline
\end{tabular}

Means designated with the same letter within the same column are not significantly different at 0.05 level of probability. CP: Crude Protein, CA: Citric Acid, SEM: Standard Error of the Mean

To cite this paper: Abd-Elsamee MO, Fathy Abbas Motawe H, Maher Selim M and Ramadan Elsherif HM (2020). Effect of Different Dietary Crude Protein Levels and Citric Acid on Broiler Chickens' Performance, Carcass Characteristics, Intestinal Morphology, and Blood Components. World Vet. J., 10 (3): 362-374. DOI: https://dx.doi.org/10.36380/scil.2020.wvj45 
Table 7. The effect of low protein broiler diets supplemented with citric acid on blood parameters at 42 days of age

\begin{tabular}{|c|c|c|c|c|c|c|c|c|c|c|c|c|}
\hline \multicolumn{7}{|c|}{ Treatments } & \multicolumn{6}{|c|}{ Parameters } \\
\hline CP & CA & $\begin{array}{c}\text { Glu. } \\
(\mathrm{mg} / \mathrm{dl})\end{array}$ & $\begin{array}{c}\text { TP } \\
(\mathrm{g} / \mathrm{dl})\end{array}$ & $\begin{array}{c}\text { Alb. } \\
(\mathrm{g} / \mathrm{dl})\end{array}$ & $\begin{array}{l}\text { Glob. } \\
\text { (g/dl) }\end{array}$ & $\begin{array}{c}\text { Hgb } \\
\text { (g/dl) }\end{array}$ & HbA1c & FA. & $\begin{array}{c}\mathrm{TC} \\
(\mathrm{mg} / \mathrm{dl})\end{array}$ & $\begin{array}{c}\mathbf{U A} \\
(\mathbf{m g} / \mathbf{d l})\end{array}$ & $\begin{array}{l}\text { AST } \\
(u / l)\end{array}$ & $\begin{array}{l}\text { ALT } \\
(\mathbf{u} / \mathbf{l})\end{array}$ \\
\hline \multicolumn{13}{|c|}{ Main effect of CP } \\
\hline $100 \%$ & -------- & 241.98 & $4.37^{\mathrm{a}}$ & $1.55^{\mathrm{a}}$ & $2.81^{\mathrm{a}}$ & 8.47 & $3.31^{\mathrm{b}}$ & $100.35^{\mathrm{b}}$ & $121.01^{\mathrm{b}}$ & 3.98 & 163.33 & $40.00^{\mathrm{a}}$ \\
\hline $90 \%$ & ------- & 241.23 & $3.59^{\mathrm{b}}$ & $1.35^{\mathrm{b}}$ & $2.24^{\mathrm{b}}$ & 8.38 & $3.71^{\mathrm{a}}$ & $123.87^{\mathrm{a}}$ & $132.66^{\mathrm{a}}$ & 3.97 & 167.50 & $30.50^{\mathrm{b}}$ \\
\hline \multicolumn{13}{|c|}{ Main effect of CA } \\
\hline ------- & 0.00 & 240.53 & 3.80 & $1.35^{\mathrm{b}}$ & 2.45 & 8.45 & $3.72^{\mathrm{a}}$ & $123.87^{\mathrm{a}}$ & $134.33^{\mathrm{a}}$ & $4.19^{\mathrm{a}}$ & 167.50 & 33.50 \\
\hline -------- & $2 \%$ & 242.68 & 4.16 & $1.55^{\mathrm{a}}$ & 2.60 & 8.41 & $3.32^{\mathrm{b}}$ & $100.35^{\mathrm{b}}$ & $119.35^{\mathrm{b}}$ & $3.76^{\mathrm{b}}$ & 163.50 & 37.00 \\
\hline \multicolumn{13}{|c|}{ CP $^{\times}$CA effect } \\
\hline $100 \%$ & $0 \%$ & 241.53 & $4.17^{\mathrm{ab}}$ & $1.45^{\mathrm{b}}$ & $2.72^{\mathrm{ab}}$ & 8.63 & $3.50^{\mathrm{b}}$ & $111.13^{\mathrm{b}}$ & $129.33^{\mathrm{b}}$ & 4.16 & 167.00 & $37.00^{\mathrm{ab}}$ \\
\hline $100 \%$ & $2 \%$ & 242.43 & $4.57^{\mathrm{a}}$ & $1.65^{\mathrm{a}}$ & $2.92^{\mathrm{a}}$ & 8.32 & $3.13^{\mathrm{c}}$ & $89.57^{\mathrm{c}}$ & $112.70^{\mathrm{c}}$ & 3.80 & 159.67 & $43.00^{\mathrm{a}}$ \\
\hline $90 \%$ & $0 \%$ & 239.53 & $3.43^{\mathrm{c}}$ & $1.25^{\mathrm{c}}$ & $2.18^{\mathrm{b}}$ & 8.27 & $3.93^{\mathrm{a}}$ & $136.61^{\mathrm{a}}$ & $139.33^{\mathrm{a}}$ & 4.23 & 168.00 & $30.00^{\mathrm{b}}$ \\
\hline $90 \%$ & $2 \%$ & 242.93 & $3.75^{\mathrm{bc}}$ & $1.45^{\mathrm{b}}$ & $2.30^{\mathrm{b}}$ & 8.50 & $3.50^{\mathrm{b}}$ & $111.13^{\mathrm{b}}$ & $126.00^{\mathrm{b}}$ & 3.73 & 167.33 & $31.00^{\mathrm{b}}$ \\
\hline SEM & & 2.7 & 0.13 & 0.40 & 0.11 & 0.07 & 0.09 & 5.06 & 2.53 & 0.09 & 7.99 & 1.88 \\
\hline \multicolumn{13}{|l|}{ P-value } \\
\hline $\mathrm{CP}$ & & 0.80 & 0.0004 & 0.01 & 0.004 & 0.50 & 0.01 & 0.01 & 0.015 & 0.69 & 0.89 & 0.006 \\
\hline CA & & 0.67 & 0.17 & 0.01 & 0.40 & 0.77 & 0.01 & 0.01 & 0.0006 & 0.006 & 0.12 & 0.37 \\
\hline $\mathrm{CP} \times \mathrm{CA}$ & & 0.17 & 0.0008 & 0.001 & 0.038 & 0.18 & 0.001 & 0.001 & 0.0001 & 0.06 & 0.18 & 0.03 \\
\hline
\end{tabular}

Means designated with the same letter within the same column are not significantly different at 0.05 level of probability. CP: Crude Protein, CA: Citric Acid, Glu: Glucose, TP: Total Protein, Alb: Albumin, Glob: Globulin, Hgb: Hemoglobin, HbA1c: Hemoglobin A1c, FA: Fructosamine, TC: Total Cholesterol, UA: Uric Acid, AST: Aspartate aminotransferase, ALT: Alanine aminotransferase, SEM: Standard error of the mean.

\section{CONCLUSION}

Broiler chickens fed a low protein diet supplemented with citric acid addition had the same performance as those with the required protein. The beneficial effect of citric acid on nutrients utilization, growth performance, and carcass may be due to the effect of citric acid on intestinal villus height, absorption area, cecal microbial content, and blood chemistry.

\section{DECLARATIONS}

\section{Authors' contribution}

All authors have equally contributed to the design of the study, data collection, data analysis writing, and revision of the manuscript. In addition, all the authors approved and agreed to the publication of the manuscript.

\section{Competing interests}

The authors have declared no competing interest.

\section{Acknowledgements}

The authors would like to appreciate the Deanship of Regional Center for food and feed, Agricultural Research Center, Giza, Egypt, for funding this study.

\section{REFERENCES}

Abdel-Fattah SA, Sanhoury MHE, and Azeem FA (2008). Thyroid activity, some blood constituents, organ morphology and performance of broiler chicks fed supplemented organic acids. International Journal of Poultry Science, 7: 215-222. DOI: https://doi.org/10.3923/ijps.2008.215.222

Adhikari P, Yadav S, Cosby D E, Cox NA, Jendza JA, and Kim WK (2020). Research Note: Effect of organic acid mixture on growth performance and Salmonella Typhimurium colonization in broiler chickens. Poultry Science. DOI: https://doi.org/10.1016/j.psj.2019.12.037

Ahmad EAM, Abdel-Kader IA, and Abdel-Wahab AA (2018). Organic acids as potential alternate for antibiotic as growth promoter in japanese quail. Egyptian Poultry Science Journal, 38 (II): 359-373. Available at: https://epsj.journals.ekb.eg/article_8202.html

Al-Saad S, Abbod M, and Abo Yones A (2014). Effects of some growth promoters on blood hematology and serum composition of broiler chickens. International Journal of Agricultural Research, 9: 265-270. DOI: https://doi.org/10.3923/ijar.2014.265.270

Alam MS, Ahmad N, Miah MA, and Islam R (2004). Effect of supplemented dietary protein on certain haematological values and meat yield characteristics of broiler birds. Bangladesh Journal of Veterinary Medicine, 2(2): 121-123. DOI https://doi.org/10.3329/bjvm.v2i2.2543

Aletor VA, Hamid II, Nieß E, and Pfeffer E. (2000). Low-protein amino acid-supplemented diets in broiler chickens: effects on performance, carcass characteristics, whole-body composition and efficiencies of nutrient utilization. Journal of the Science of

To cite this paper: Abd-Elsamee MO, Fathy Abbas Motawe H, Maher Selim M and Ramadan Elsherif HM (2020). Effect of Different Dietary Crude Protein Levels and Citric Acid on Broiler Chickens' Performance, Carcass Characteristics, Intestinal Morphology, and Blood Components. World Vet. J., 10 (3): 362-374. DOI: 
Food and Agriculture, 80(5): 547-554. DOI: https://doi.org/10.1002/(SICI)1097-0010(200004).

Ali FHA, Ashour ZA, Shahin RY, Zaki WK, Ragab SB, and Attia MY (2013). Role of intestinal microflora (Lactobacillus Acidophilus) in phagocytic function of leukocytes in type 2 diabetic patients. Egyptian Journal of Medical Human Genetics, 14(1):95-101. DOI: https://doi.org/10.1016/j.ejmhg.2012.10.003

Allameh S and Toghyani M. (2019). Effect of dietary valine supplementation to low protein diets on performance, intestinal morphology and immune responses in broiler chickens. Livestock Science, 229:137-144. DOI: https://doi.org/10.1016/j.livsci.2019.09.025

Anguizola J, Matsuda R, Barnaby OS, Hoy K.S, Wa C, DeBolt E, Koke M, and Hage DS (2013). Glycation of human serum albumin. Clinica Chimica Acta, 425: 64-76. DOI: https://doi.org/10.1016/j.cca.2013.07.013

Barekatain R., Nattrass G, Tilbrook A J, Chousalkar K, and Gilani S (2019). Reduced protein diet and amino acid concentration alter intestinal barrier function and performance of broiler chickens with or without synthetic glucocorticoid. Poultry Science, 98(9): 3662-3675. DOI: https://doi.org/10.3382/ps/pey563

Belloir P, Méda B, Lambert W, Corrent E, Juin H, Lessire M, and Tesseraud S(2017). Reducing the CP content in broiler feeds: impact on animal performance, meat quality and nitrogen utilization. Animal, 11(11): 1881-1889. DOI: https://doi.org/10.1017/S1751731117000660

Bhonsle HS, Korwar AM, Kote SS, Golegaonkar SB, Chougale AD, Shaik, ML, Dhande NL, Giri AP, Shelgikar KM, Boppana R et al. (2012). Low plasma albumin levels are associated with increased plasma protein glycation and HbA1c in diabetes. Journal of proteome research, 11(2): 1391-1396. DOI: $\underline{10.1021 / \mathrm{pr} 201030 \mathrm{~m}}$

Biggs P and Parsons CM (2008). The effects of several organic acids on growth performance, nutrient digestibilities, and cecal microbial populations in young chicks. Poultry science, 87(12): 2581-2589. DOI: https://doi.org/10.3382/ps.2008-00080

Bregendahl K, Sell JL, and Zimmerman DR (2002). Effect of low-protein diets on growth performance and body composition of broiler chicks. Poultry Science, 81(8): 1156-1167. DOI: https://doi.org/10.1093/ps/81.8.1156

Cesare A, Faria do Valle İ, Sala C, Sirri F, Astolfi A, Castellani G, and Manfreda G (2019). Effect of a low protein diet on chicken ceca microbiome and productive performances. Poultry Science, 98(9):3963-3976. DOI: https://doi.org/10.3382/ps/pez132

Cohen RM, Holmes YR, Chenier TC, and Joiner CH (2003). Discordance between HbA1c and fructosamine: evidence for a glycosylation gap and its relation to diabetic nephropathy. Diabetes care, 26(1): 163-167. DOI: https://doi.org/10.2337/diacare.26.1.163

Coles EH (1974). "Veterinary Clinical pathology" $2^{\text {nd }}$ Ed. W.B. Saudners Co. Philadelphia and London. PP. $211-213$.

Dehghani N and Jahanian R (2012). Interactive impacts of dietary organic acid and crude protein level on performance and gut morphology of broiler chicken. World`s Poultry Science Journal. 3: 345-353.

Dehghani-Tafti N and Jahanian R (2016). Effect of supplemental organic acids on performance, carcass characteristics, and serum biochemical metabolites in broilers fed diets containing different crude protein levels. Animal Feed Science and Technology, 211: 109-116. DOI: https://doi.org/10.1016/j.anifeedsci.2015.09.019

Duncan DB (1955). Multiple range and multiple Biometrics, 11:1-42.

El-Afifi ShF, El-Mednay NM, and Attia M (2001). Effect of citric acid supplementation in broiler diets on performance and intestinal microflora. Egyptian Poultry Science, 21: 491-505.

Folorunso OR, Adesua AA, and Onibi GE (2014). Response of broiler chickens to diets of varying protein contents under ad libitum and skip-a-day feeding regimes. African Journal of Agricultural Research, 9(1):113-118. DOI: https://doi.org/10.5897/AJAR12.1318

Ghazalah AA, Atta AM, Elkloub K, Moustafa MEL, and Shata RFH (2011). Effect of dietary supplementation of organic acids on performance, nutrients digestibility and health of broiler chicks. International Journal of Poultry Science, 10: 176-184. DOI: https://doi.org/10.3923/ijps.2011.176.184

Gheorghe A (2013). Effects of dietary protein level on protein deposition in broilers: 1. Productive performance and carcass characteristics. Bulletin of University of Agricultural Sciences and Veterinary Medicine Cluj-Napoca. Animal Science and Biotechnologies, 70(2): 266-273. DOI: http://dx.doi.org/10.15835/buasvmcn-asb:70:2:9253

Golian A, Azghadi A, and Pilevar M (2010). Influence of various levels of energy and protein on performance and humoral immune responses in broiler chicks. Global Veterinaria, 4(5): 434-440. Available at: https://www.idosi.org/gv/gv4(5)10/2.pdf

Goodarzi Boroojeni F, Vahjen W, Männer K, Blanch A, Sandvang D, and Zentek J (2018). Bacillus subtilis in broiler diets with different levels of energy and protein. Poultry Science, 97(11): 3967-3976. DOI: https://doi.org/10.3382/ps/pey265

Gous RM, Emmans GC, Broadbent LA, and Fisher C. (1990). Nutritional effects on the growth and fatness of broilers. British Poultry Science, 31(3): 495-505. DOI: https://doi.org/10.1080/00071669008417281

Guilbaud A, Niquet-Leridon C, Boulanger E, and Tessier FJ (2016). How can diet affect the accumulation of advanced glycation endproducts in the human body?. Foods, 5(4):84. DOI: https://doi.org/10.3390/foods5040084

Haque MN, Islam KM, Akbar MA, Chowdhury R, Khatun M, Karim MR, and Kemppainen BW (2010). Effect of dietary citric acid, flavomycin and their combination on the performance, tibia ash and immune status of broiler. Canadian journal of animal science, 90(1): 57-63. DOI: https://doi.org/10.4141/CJAS09048

Hernández F, López MJ, Martínez S, Catala P, and Madrid J (2012). Effect of low-protein diets and single sex onproduction performance, plasma metabolites, digestibility, and nitrogen excretion in 1- to 48-day-old broilers. Poultry Science, 91(3): 683692. DOI: https://doi.org/10.3382/ps.2011-01735

Hilliar M, Keerqin C, Girish CK, Barekatain R, Wu SB, and Swick RA (2020). Reducing protein and supplementing crystalline amino acids, to alter dietary amino acid profiles in birds challenged for subclinical necrotic enteritis. Poultry Science, 99(4):2048-2060.

To cite this paper: Abd-Elsamee MO, Fathy Abbas Motawe H, Maher Selim M and Ramadan Elsherif HM (2020). Effect of Different Dietary Crude Protein Levels and Citric Acid on Broiler Chickens' Performance, Carcass Characteristics, Intestinal Morphology, and Blood Components. World Vet. J., 10 (3): 362-374. DOI: https://dx.doi.org/10.36380/scil.2020.wvj45 
Honma A, Ogawa C, Sugahara M, Fujimura S, and Kita K (2017). Influence of varying dietary protein levels on glycation of albumin, tryptophan and valine in the plasma of chickens. The Journal of Poultry Science, 54(3):242-246. DOI: https://doi.org/10.2141/jpsa.0160146

Islam KMS, Schaeublin H, Wenk C, Wanner M, and Liesegang A (2011). Effect of dietary citric acid on the performance and mineral metabolism of broiler. Journal of Animal Physiology and Animal Nutrition, 96(5): 808-817. DOI: https://doi.org/10.1111/j.1439-0396.2011.01225.x

Jahanian R (2009). Immunological responses as affected by dietary protein and arginine concentrations in starting broiler chicks. Poultry Science, 88(9): 1818-1824. DOI: https://doi.org/10.3382/ps.2008-00386

Javaid S, Anjum MI, and Akram M (2012). Effect of dietary protein and energy level on proximate composition of breast and thigh meat in white leghorn layers at molt and post molt production stages. Pakistan Veterinary Journal, 32, 483-488. Available at: https://agris.fao.org/agris-search/search.do?recordID=DJ2012081047

Kamran Z (2010). Effect of low protein diets with varying energy to protein ratios supplemented with limiting amino acids on performance of broilers. $\mathrm{PhD}$ Thesis. University Of Agriculture, Faisalabad Pakistan, p.125. Available at: http://prr.hec.gov.pk/jspui/handle/123456789/858

Kamran Z, Sarwar M, Nisa M, Nadeem MA, and Mahmood S (2010). Effect of low levels of dietary crude protein with constant metabolizable energy on nitrogen excretion, litter composition and blood parameters of broilers. International Journal of Agriculture and Biology, 12: 401-405.

Katanbaf MN, Dunnington EA, and Siegel PB (1989). Restricted feeding in early and late-feathering chickens. Growth and physiological responses. Poultry Science, 68:344-351. DOI: https://doi.org/10.3382/ps.0680344

Kermani ZA, Shahir MH, and Baradaran N (2017). Effect of gelatin supplementation on growth performance and blood metabolites of broiler chickens fed diets varying in crude protein. Livestock Science, 201:5-12. DOI: https://doi.org/10.1016/j.livsci.2017.04.008

Khosravinia H, Nourmohammadi R, and Afzali N (2015). Productive performance, gut morphometry, and nutrient digestibility of broiler chicken in response to low and high dietary levels of citric acid. Journal of Applied Poultry Research, 24(4):470-480. DOI: https://doi.org/10.3382/japr/pfv050

Lakshmi KV, Reddy AR, Sunder GS, and Reddy VR (2016). Supplementation of lactic and citric acid in antibiotic free diets and their influence on performance, meat yield and immune response of broiler chickens. Indian Journal of Poultry Science, 51(1): 42-47. DOI: https://doi.org/10.5958/0974-8180.2016.00013.1

Laudadio V, Passantino L, Perillo A, Lopresti G, Passantino A, Khan RU, and Tufarelli V (2012). Productive performance and histological features of intestinal mucosa of broiler chickens fed different dietary protein levels. Poultry Science, 91(1):265-270. DOI: https://doi.org/10.3382/ps.2011-01675

Liu SY, Selle PH, Raubenheimer D, Gous R.M, Chrystal PV, Cadogan DJ, Simpson SJ, and Cowieson AJ (2017). Growth performance, utilisation and carcass composition respond to dietary protein concentrations in broiler chickens but responses are modified by dietary lipid levels. British Journal of Nutrition, 118(4): 250-262. DOI: https://doi.org/10.1017/S0007114517002070

Macelline SP, Wickramasuriya SS, Cho HM, Kim E, Shin T.K, Hong JS, Kim JC, Pluske JR, Choi HJ, and Hong YG et al. (2020). Broilers fed a low protein diet supplemented with synthetic amino acids maintained growth performance and retained intestinal integrity while reducing nitrogen excretion when raised under poor sanitary conditions. Poultry Science, 99(2):949-958. DOI: https://doi.org/10.1016/i.psj.2019.10.035

Mahmoud KZ, Obeidat BS, Al-Sadi MZ, and Hatahet SR (2017). Effect of Bacillus subtilis supplementation and dietary crude protein level on growth performance and intestinal morphological changes of meat type chicken. Livestock Science, 195: 99-104. DOI: https://doi.org/10.1016/j.livsci.2016.11.015

Makino R, Sugahara M, and Kita K (2015). Nutritional evaluation of glycated valine and tryptophan as a precursor for protein synthesis in chicken embryo myoblasts. The Journal of Poultry Science, 52: 23-27. DOI: https://doi.org/10.2141/jpsa.0130185

Malomo GA, Bolu SA, and Olutade SG (2013). Effects of dietary crude protein on performance and nitrogen economy of broilers. Sustainable Agriculture Research, 2(3):52-57. DOI: https://doi.org/10.5539/sar.v2n3p52

Mohamed EA, Ali OH, Malik EE, and Yousif IA (2012). Effect of season and dietary protein level on some haematological parameters and blood biochemical compositions of three broiler strains. International Journal of Poultry Science, 11(12):787793. DOI: https://doi.org/10.3923/ijps.2012.787.793

Mohammadagheri N, Najafi R, and Najafi G (2016). Effects of dietary supplementation of organic acids and phytase on performance and intestinal histomorphology of broilers. In Veterinary Research Forum, 7(3): 189-195. Available at: https://www.ncbi.nlm.nih.gov/pmc/articles/PMC5094164/pdf/vrf-7-189.pdf.

Namroud NF; Shivazad M, and Zaghari M (2008). Effect of fortifying low crude protein diet with crystalline amino acids on performance, blood ammonia level and excreta characteristics of broiler chicks. Poultry Science, 87: 2250-2258. DOI: https://doi.org/10.3382/ps.2007-00499

National Research Council (NRC) (1994). Nutrient Requirements of Poultry. $9^{\text {th }}$ Edition, National Academy of sciences. Washington, DC., USA. Available at: https://www.nap.edu/catalog/2114/nutrient-requirements-of-poultry-ninth-revised-edition-1994

Nosrati M, Javandel F, Camacho LM, Khusro A, Cipriano M, Seidavi A, and Salem AZM (2017). The effects of antibiotic, probiotic, organic acid, vitamin $\mathrm{C}$, and Echinacea purpurea extract on performance, carcass characteristics, blood chemistry, microbiota, and immunity of broiler chickens. Journal of Applied Poultry Research, 26(2): 295-306. DOI: https://doi.org/10.3382/japr/pfw073

Nourmohammadi R, and Afzali N (2013). Effect of citric acid and microbial phytase on small intestinal morphology in broiler 
Nourmohammadi R, and Khosravinia H (2015). Acidic stress caused by dietary administration of citric acid in broiler chickens. Archiv fuer Tierzucht, 58(2): 309-315. DOI: https://doi.org/10.5194/aab-58-309-2015

Panda AK, Rao SV, Raju MVLN, and Sunder GS (2009). Effect of butyric acid on performance, gastrointestinal tract health and carcass characteristics in broiler chickens. Asian-Australasian Journal of Animal Sciences, 22(7): 1026-1031. DOI: https://doi.org/10.5713/ajas.2009.80298

Park JH and Kim IH (2019). The effects of betaine supplementation in diets containing different levels of crude protein and methionine on the growth performance, blood components, total tract nutrient digestibility, excreta noxious gas emission, and meat quality of the broiler chickens. Poultry Science, 98(12): 6808-6815. DOI: https://doi.org/10.3382/ps/pez412.

Paul SK, Halder G, Mondal MK, and Samanta G (2007). Effect of organic acid salt on the performance and gut health of broiler chicken. Journal of Poultry Science, 44(4): 389-395. DOI: https://doi.org/10.2141/jpsa.44.389.

Polycarpo GV, Andretta I, Kipper M, Cruz-Polycarpo VC, Dadalt JC, Rodrigues PHM, and Albuquerque R (2017). Meta-analytic study of organic acids as an alternative performance-enhancing feed additive to antibiotics for broiler chickens. Poultry science, 96(10): 3645-3653. DOI: https://doi.org/10.3382/ps/pex178

Ravangard AH, Houshmand M, Khajavi M, and Naghiha R (2017). Performance and cecal bacteria counts of broilers fed low protein diets with and without a combination of probiotic and prebiotic. Brazilian Journal of Poultry Science, 19(SPE): 75-82. DOI: https://doi.org/10.1590/1806-9061-2016-0319

Roy SC, Alam MS, Ali MA, Chowdhury SD, and Goswami C (2010). Different levels of protein on the performance of synthetic broiler. Bangladesh Journal of Veterinary Medicine, 8(2): 117-122. DOI: https://doi.org/10.3329/bjvm.v8i2.11193

Sabour S, Tabeidian SA, and Sadeghi G (2019). Dietary organic acid and fiber sources affect performance, intestinal morphology, immune responses and gut microflora in broilers. Animal Nutrition, 5(2): 156-162. DOI: https://doi.org/10.1016/j.aninu.2018.07.004

Samanta S, Haldar S, and Ghosh TK (2010). Comparative efficacy of an organic acid blend and bacitracin methylene disalicylate as growth promoters in broiler chickens: effects on performance, gut histology and small intestinal milieu. Veterinary Medicine International, pp. 645-650. DOI: https://doi.org/10.4061/2010/645150.

Samanta S, Haldar S, and Ghosh TK (2008). Production and carcase traits in broiler chickens given diets supplemented with inorganic trivalent chromium and an organic acid blend. British poultry science, 49(2): 155-163. DOI: https://doi.org/10.1080/00071660801946950

SAS Institute (2004). SAS/STAT User's guide statistics. SAS institute INC., Cary. NC, USA.

Selim MM (2015). Effect of different levels of protein, methionine and folic acid on growth performance of quails. M.S Thesis, Cairo University, Egypt, p.102. Available at: http://srv2.eulc.edu.eg

Sigolo S, Zohrabi Z, Gallo A, Seidavi A, and Prandini A (2017). Effect of a low crude protein diet supplemented with different levels of threonine on growth performance, carcass traits, blood parameters, and immune responses of growing broilers. Poultry Science, 96(8): 2751-2760. DOI: https://doi.org/10.3382/ps/pex086

Sharifuzzaman M, Sharmin F, Khan MJ Shishir MSR, Akter S, Afrose M, and Jannat HE (2020) Effects of Low Energy Low Protein Diet with Different Levels of Citric Acid on Growth, Feed Intake, FCR, Dressing Percentage and Cost of Broiler Production. Journal of Agriculture and Veterinary Science, 13(3):33-41. DOI: https://doi.org/10.9790/2380-1303023341

Srilatha T, Reddy VR, Preetam VC, Rao SV, and Reddy YR (2018). Effect of different levels of dietary crude protein on the growth performance and carcass characteristics of commercial broilers at different phases of growth. Indian Journal of Animal Research, 52(4): 559-563. DOI : https://doi.org/10.18805/ijar. B-3255

Sultan, A, Khan S, Khan S, Chand N, Khan MS, and Maris H (2018). Effect of organic acid blend on carcass yield, nutrient digestibility and tibia ash during starter phase of broiler chicks. Pakistan Journal of Zoology, 50(4): 1483-1488. DOI: http://dx.doi.org/10.17582/journal.pjz/2018.50.4.1483.1488

Swennen Q, Janssens GPJ, Millet S, Vansant G, Decuypere E, and Buyse J (2005). Effects of substitution between fat and protein on feed intake and its regulatory mechanisms in broiler chickens: Endocrine functioning and intermediary metabolism. Poultry Science, 84(7): 1051-1057. DOI: https://doi.org/10.1093/ps/84.7.1051

Tanzin M, Islam KMS, Debi MR, and Islam MR (2015). Effect of citric acid, herbal feed additive and their combination on the performance of broiler. Bangladesh Journal of Animal Science, 44(3): 143-150. DOI: 10.3329/bjas.v44i3.26364

Tarsewics Z, Szczerbińska D, Ligocki M, Wiercińska M, Jakubowska M, and Romaniszyn K (2006) The effect of differentiated dietary protein level on the performance of breeder quails. Animal Science Papers and Reports, 24(3): 207-216. Available at: http://www.ighz.edu.pl/

Tiwari S, Bothale M, Hasan I, Kulkarni MJ, Sayyad MG, Basu R, Basu A, and Unnikrishnan AG (2015). Association between serum albumin and glycated hemoglobin in Asian Indian subjects. Indian journal of endocrinology and metabolism, 19(1): 52:55. DOI: https://doi.org/10.4103/2230-8210.144631

Trinder P (1969). Determination of blood glucose using an oxidase-peroxidase system with a non-carcinogenic chromogen. Journal of clinical pathology, 22(2): 158-161. DOI: https://doi.org/10.1136/jcp.22.2.158

Ur Rehman Z, Ul Haq A, Akram N, Abd El-Hack ME, Saeed M, Rehman SU, Meng C, Alagawany M, Sayab M, Dhama K, and Ding C (2016). Growth performance, intestinal histomorphology, blood hematology and serum metabolites of broilers chickens fed diet supplemented with graded levels of acetic acid. International Journal of Pharmacology, 12(8): 874-883. DOI: https://doi.org/10.3923/ijp.2016.874.883

Van Kampen EJ and Zillstra WG (1983). Spectrophotometry of hemoglobin and hemoglobin derivatives. In Advances in clinical chemistry. 23:199-257. DOI: https://doi.org/10.1016/S0065-2423(08)60401-1

Yu D, Zhu W, and Hang S (2019). Effects of low-protein diet on the intestinal morphology, digestive enzyme activity, blood urea 373

To cite this paper: Abd-Elsamee MO, Fathy Abbas Motawe H, Maher Selim M and Ramadan Elsherif HM (2020). Effect of Different Dietary Crude Protein Levels and Citric Acid on Broiler Chickens' Performance, Carcass Characteristics, Intestinal Morphology, and Blood Components. World Vet. J., 10 (3): 362-374. DOI: https://dx.doi.org/10.36380/scil.2020.wvj45 
nitrogen, and gut microbiota and metabolites in weaned pigs. Archives of Animal Nutrition, 73(4): 287-305. DOI: https://doi.org/10.1080/1745039X.2019.1614849

Zhu Y, Lin X, Zhao F, Shi X, Li H, Li Y, Zhu W, Xu X, Li C, and Zhou G (2015). Meat, dairy and plant proteins alter bacterial composition of rat gut bacteria. Scientific reports, 5, 15220. DOI: $\underline{\text { https://doi.org/10.1038/srep15220 }}$ 